\title{
Comparison of Vitamin Losses in Vegetables Due to Various Cooking Methods
}

\author{
D. RuMm-Kreuter and I. DeMMEL
}

Alfa Institut Eltville (FDG)

\begin{abstract}
Summary Preparing vegetables with heat the contents of their constituents will change to a various extend. Particularly the water-soluble and the heat-sensitive vitamins are affected. At an early stage the vitamin $\mathrm{C}$ losses were investigated, because of vitamin C's indicating function for oxidations and leaching-out processes $(1,2,7,11-13,15,17)$. The degree of vitamin losses is influenced by various factors, for example the type of food, variety of vegetables, the way of cutting, preparation, duration and method of cooking. The influence of the various cooking methods with regard to the losses of certain water-soluble vitamins will be discussed.

Key Words cooking methods, ascorbic acid, folic acid, thiamine, riboflavin, niacin, pyridoxine
\end{abstract}

Foods are prepared in order to become edible and enjoyable. The choice of the cooking method depends on the individual or cultural dietary habits.

By preparing food with heat, not only alterations in carbohydrates, fats and proteins, but also alterations in the vitamins and minerals take place to a various extent.

Particularly the water soluble and heat sensitive vitamins are affected. Therefore the main subject of this report is the reduction in the content of vitamins like Ascorbic acid, Thiamine, Riboflavin, Niacin, Pyridoxine and Folic acid caused by the preparation of food with heat.

The degree of vitamin losses is influenced by the vitamin's sensitivity to factors like light, oxygen, water and temperature.

According to Paulus (13) the losses are higher, the longer the period of time when the different factors can affect the food and the greater the surface of the food.

Ascorbic acid is often used as an indicating vitamin, because it is very sensitive to heat and to water. The Ascorbic acid losses during the cooking process are caused by the lixiviation and the destruction by oxidation. According to Weise (19) the enzymatic activity of the oxidases reaches the highest level at 40 degrees celsius. Higher temperatures destroy the enzymes. The irreversible inactivation of phenoloxidase takes place between 70 and 80 degrees celsius, the inactivation of 
peroxidase between 80 and 100 degrees celsius [(Hottenroth (8), Zobel (20)].

The amount of vitamin losses due to cooking depends on several factors, for example, the type of food, the variety of food, the way of cutting, preparation, duration and method of cooking. Due to the high degree of variability a direct comparison of the results of the numerous investigations is difficult [Klein $(9,10)$, Warthesen (18), Augustin (1), Somogyi (14)]. Even a slight alteration could lead to different results.

\section{DISCUSSION OF DIFFERENT RESULTS}

Many investigators are engaged in the Ascorbic acid losses due to cooking. Blumenthal (3) compared for example the Ascorbic acid content in fresh Spinach when boiled (with water), steamed (without adding water) and cooked in a pressure cooker at approximately 120 degrees celsius.

The results show a distinctly higher Ascorbic acid content after the steaming method as opposed to pressure cooking or boiling. Pressure cooking and boiling produced similar ascorbic acid results.

Tests carried out by Meier-Ploeger (12), Somogyi (14) and Tempelhoff (17) confirm that after the steaming method without adding water the most significant Ascorbic acid content was found to be present. Pressure-cooking, however, in these tests showed better results than boiling.

Bielig (2), Herrmann (7) and Szöke (16) investigated the influence on Ascorbic acid content when it is affected by different pressure levels. They determined that after low pressures the Ascorbic acid content was greater than after high pressures.

Of course, cooking duration and the type of foodstuff play an important role as shown by some of our unpublished tests. Products, which need a long cooking period, like cabbage and bean soup, showed a higher Ascorbic acid content after pressure cooking than after steaming. On the other hand, products, which require only a short cooking period, like spinach and kohlrabi in slices, contained a higher concentration of Ascorbic acid after steaming rather than after pressure cooking (Rumm-Kreuter, 1986).

Further interesting cooking methods are stirfrying and microwave cooking.

Table 1. Ascorbic acid contents $(\mathrm{mg} / 100 \mathrm{~g})$ in fresh spinach and in spinach after different cooking methods.

\begin{tabular}{lcc}
\hline \multicolumn{1}{c}{ Process } & Ascorbic acid $(\mathrm{mg} / 100 \mathrm{~g})$ & Losses \\
\hline Fresh & 43 & - \\
Boiling & $17(9-21)$ & ca. $60,0 \%$ \\
Steaming & $23(11-33)$ & ca. $46,5 \%$ \\
Pressure cooking $\left(120^{\circ} \mathrm{C}\right)$ & $18(8-25)$ & ca. $58,0 \%$ \\
\hline
\end{tabular}

Blumenthal (1980). 
Table 2. Ascorbic acid contents (\%) in broccoli and green beans after different cooking methods.

\begin{tabular}{lcc}
\multicolumn{1}{c}{ Process } & Broccoli & Green beans \\
\hline Stirfrying & 76,6 & 57,5 \\
Microwave cooking & 56,8 & 58,9 \\
Boiling & 44,8 & 59,6 \\
Steaming & 74,2 & 76,0 \\
\hline
\end{tabular}

Eheart (1965).

Table 3. Mean reduced Ascorbic acid and Folic acid content of spinach.

\begin{tabular}{lcc}
\hline $\begin{array}{c}\text { Vegetable } \\
\text { Spinach }\end{array}$ & $\begin{array}{c}\text { Reduced Ascorbic acid } \\
(\mathrm{mg} / 100 \mathrm{~g} \mathrm{WB})\end{array}$ & $\begin{array}{c}\text { Total Folic acid } \\
(\mathrm{mg} / 100 \mathrm{~g} \mathrm{WB})\end{array}$ \\
\hline Fresh & $26,5 \pm 11,30(\mathrm{a})$ & $1,61 \pm 58,0(\mathrm{NS})$ \\
Microwave cooked & $13,5 \pm 6,26$ & $1,83 \pm 54,2(\mathrm{NS})$ \\
Steamed & $17,0 \pm 8,33$ & $1,57 \pm 58,5(\mathrm{NS})$ \\
\hline
\end{tabular}

Klein (1981).

$\mathbf{a}=$ Values are means and standard deviations for light replications. Values in the same column with unlike letters are significantly different $(P<0,05)$. NS $=$ indicates differences, which are not significant.

Eheart (5) has compared stirfrying-which is mostly practised in Asian countries-, microwave cooking, steaming and boiling with regard to the Ascorbic acid content in broccoli and beans.

With beans, steaming proved itself to be the most favorable cooking methodand the other three cooking methods were, in respect to the Ascorbic acid content, practically identical. With broccoli the stirfry method proved to be the most successful. The steaming process showed comparable results. The microwave process came out clearly poorer. The boiling method was the worst auf all in this investigation.

Klein $(9,10)$ in his tests produced similar low Ascorbic acid findings when using the microwave cooking method as opposed to steaming. This effect is probably caused by the larger quantity of food decided upon ( $400 \mathrm{~g}$ of Spinach). The duration of the microwave treatment increases with a larger quantity of food. A number of investigators have reported, that ascorbic acid losses were similar in microwave cooked and otherwise cooked vegetables at the same ratio of water used.

Together with Ascorbic acid the Folic acid level was also determined. The total Folic acid content was not significantly influenced by these cooking methods. The microwave cooking showed somewhat higher results than steaming.

The Warthesen publication (18) showed very different Ascorbic acid changes when comparing boiling (with water), steaming (without adding water) and 
D. RUMM-KREUTER and I. DEMMEL

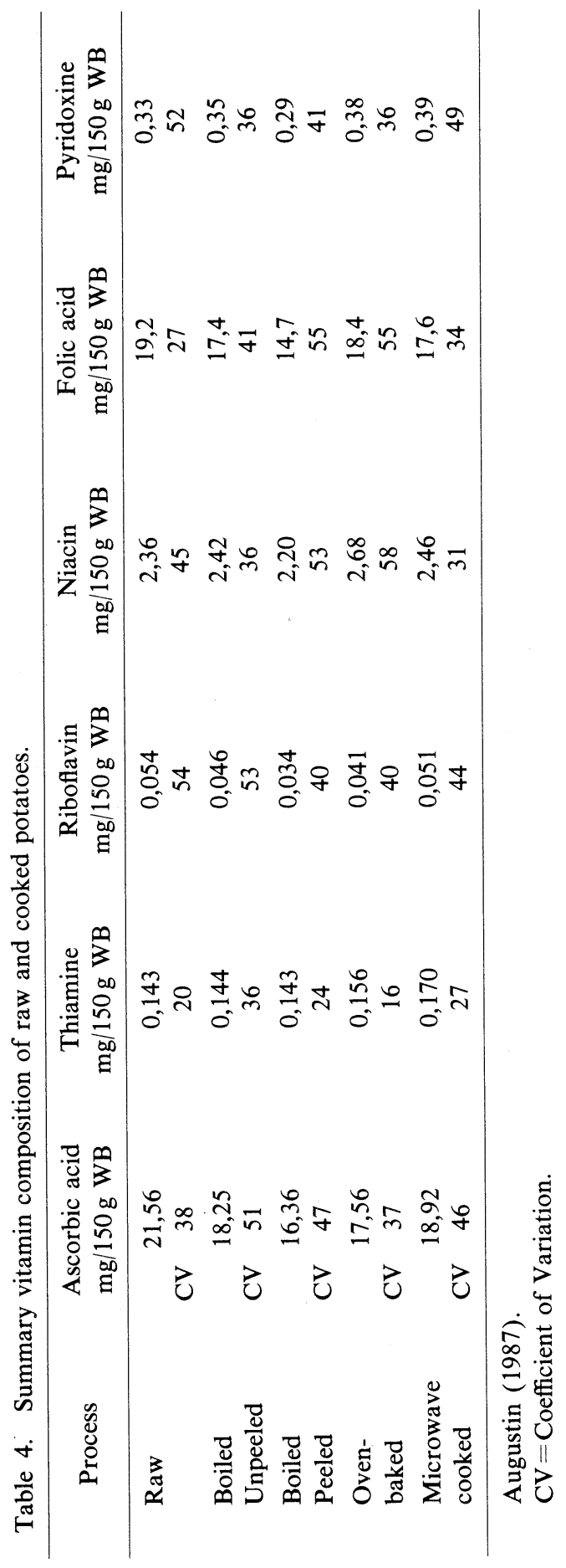


Table 5. The mean and the standard deviation of the Ascorbic acid, Thiamine and Riboflavin content of cooked vegetables prepared by waterless and conventional cooking methods.

\begin{tabular}{llccc}
\hline Vegetable & $\begin{array}{l}\text { Cooking } \\
\text { method }\end{array}$ & $\begin{array}{c}\text { Ascorbic acid } \\
\mathrm{mg} / 100 \mathrm{~g}\end{array}$ & $\begin{array}{c}\text { Thiamine } \\
\mathrm{mg} / 100 \mathrm{~g}\end{array}$ & $\begin{array}{c}\text { Riboflavin } \\
\mathrm{mg} / 100 \mathrm{~g}\end{array}$ \\
\hline Carrots & Steaming & - & $0,07 \pm 0,00$ & $0,06 \pm 0,01$ \\
& Boiling & - & $0,04 \pm 0,01$ & $0,04 \pm 0,01$ \\
Cabbage & Steaming & $51,7 \pm 2,1$ & $0,09 \pm 0,01$ & $0,03 \pm 0,00$ \\
& Boiling & $28,3 \pm 0,6$ & $0,05 \pm 0,01$ & $0,02 \pm 0,00$ \\
Potatoes & Steaming & $5,3 \pm 0,6^{*}$ & $0,03 \pm 0,02^{*}$ & $0,02 \pm 0,00$ \\
& Boiling & $3,0 \pm 1,7^{*}$ & $0,02 \pm 0,01^{*}$ & $0,02 \pm 0,00$ \\
& Steaming & $12,7 \pm 2,1$ & $0,26 \pm 0,01^{*}$ & $0,15 \pm 0,01$ \\
& Boiling & $5,3 \pm 2,5$ & $0,20 \pm 0,04^{*}$ & $0,09 \pm 0,00$ \\
\hline
\end{tabular}

Martinsen (1984). *Values in column with the same superscript for a specific species were not significantly different $(p<0,05)$.

microwave cooking of different vegetables. The highest levels of Ascorbic acid were shown after steaming and the microwave cooking method. The boiling method came out definately as the worst process.

Augustin (1) carried out tests on potatoes, boiled with and without skins, baked (with skins) and microwave cooked to observe the reaction on the Ascorbic acid, Thiamine, Riboflavin, Niacin, Folic acid and Pyridoxine contents.

A comparison of these cooking methods show the following results:

Cooking with a microwave oven the Ascorbic acid, Thiamine, Riboflavin and Folic acid had the best conservation. The favorable vitamin content with microwave cooking was probably due to the fact that smaller portions and consequently shorter cooking durations were used. For all these vitamins, cooking potatoes without skins proved to be worse than cooking potatoes with skins. Niacin and Pyridoxine were hardly affected by the cooking procedure. Also with Thiamine only few losses were observed. But this result does not conform to other publications, for example from Martinsen (11) and Somogyi (15). They noted changes in the Thiamine content with several different cooking methods.

According to Martinsen's investigations (11) significant differences were determined with regard to vitamin B-group's reaction after preparing food with heat. During his test three types of vegetables and potatoes were steamed (without adding water) or boiled (with water) and the vitamins Ascorbic acid, Thiamine and Riboflavin were measured. The Ascorbic acid content in cabbage and peas was significantly higher after steaming than after boiling. With potatoes the difference was not noteworthy. Probably this effect is due to the fact that the potatoes were cooked with skins. The Thiamine content in carrots and cabbage was also considerably higher after steaming than after boiling. With peas and potatoes no significant changes were noted. The Riboflavin content in carrots, cabbage and 
Table 6. Thiamine losses (\%) in potatoes and vegetables prepared by different cooking methods.

\begin{tabular}{lcccc}
\hline \multicolumn{1}{c}{ Product } & Steaming & $\begin{array}{c}\text { Pressure cooking } \\
\left(120^{\circ} \mathrm{C}\right)\end{array}$ & Boiling & $\begin{array}{c}\text { Test's quantity } \\
\text { n }\end{array}$ \\
\hline Potatoes & 14 & 24 & 23 & 22 \\
Celery & 14 & 14 & 14 & 15 \\
Spinach & 18 & 33 & 59 & 12 \\
Cabbage & 27 & 35 & 66 & 10 \\
Brussel sprouts & 13 & 18 & 30 & 19 \\
Cauliflower & 19 & 26 & 46 & 15 \\
Zucchini & 11 & 18 & 26 & 12 \\
\hline
\end{tabular}

Somogyi (1978).

Table 7. Thiamine, Riboflavin and Niacin content of raw and processed chick peas (mg/100 g).

\begin{tabular}{lccc}
\hline \multicolumn{1}{c}{ Process } & Thiamine & Riboflavin & Niacin \\
\hline Raw & 0,66 & 0,47 & 2,0 \\
Boiled & 0,20 & 0,08 & 1,7 \\
Pressure cooked $\left(120^{\circ} \mathrm{C}\right)$ & 0,14 & 0,03 & 2,0 \\
\hline
\end{tabular}

Geervani (1980).

peas was noticeably higher after steaming than after boiling.

These results conform to previously published statements. Also Somogyi (15) recorded similar results with regard to the Thiamine content. He tested several vegetables and one type of potatoes which were prepared with the cooking methods boiling (with water), steaming (without adding water) and pressure cooking.

When comparing the cooking methods steaming, pressure cooking and boiling the results showed that also the cooking method steaming was the most successful in respect to the Thiamine content-with the exception of celery.

A few tests dealt with the pulses group. Geervani (6) tested for changes in Thiamine, Riboflavin and Niacin content after boiling and pressure cooking. The results are described for the chosen example of pulses (chick pea).

Here too, the Thiamine content was affected by different cooking methods. Differing to the Somogyi's (15) publication the boiling method came out more favorably for the Thiamine and Riboflavin content than pressure cooking. Perhaps this discrepancy could be explained by the level of pressure. Geervani (6) used a higher pressure. The Niacin content was lower after boiling than after pressure cooking. Pressure cooking showed favorable results for the vitamin Niacin's content.

Blumenthal (4) described similar results with regard to the Niacin content. $\mathrm{He}$ tested the effect of pressure cooking on the Thiamine and Niacin content in potatoes. The Niacin levels had remained successfully high, the Thiamine content 
was recorded to be approximately $87 \%$.

To summerise the following conclusions can be drawn:

- Ascorbic acid undergoes the greatest changes within the watersoluble vitamin group.

- With regard to the Thiamine content different results as a consequence of different cooking methods have been recorded. Some authors found no changes but most of them noted Thiamine losses.

- Niacin is hardly affected by cooking methods. There are practically no losses.

- Folic acid, Riboflavin and Pyridoxine show small losses through cooking. Previous publications record higher losses in Folic acid than more recent ones.

- Regularly steaming emerges as the most successful cooking method with regard to the retention of the vitamin content.

- Stirfrying distinguished itself as an attractive cooking method.

- Pressure cooking is often more favorable for vitamin retention than Boiling.

- Microwave cooking is subject to differing data. This is due to differing microwave capabilities, food quantities and the length of time between the first publication (beginning of the 60's) and now. In the meantime the analytical methods and the microwave ovens have improved. For those reasons extensive tests on microwave cooking are needed in the very near future.

\section{REFERENCES}

1) Augustin, J., Johnson, S. R., Teitzel, C., True, R. H., Hogan, J. M., Toma, R. B., Shaw, R. L., and Deutsch, R. M. (1987): Changes in the nutrient composition of potatoes during home preparation II. Vitamins. Am. Potato J., 55, 653-662.

2) Bielig, H. J., Schurz-Gursch, W. H., and Treptow, H. (1977): Vergleichende Untersuchungen an Kartoffeln mittels unterschiedlicher Garverfahren. Ernähr. Umsch., 24, 403-408.

3) Blumenthal, A., Meier, M., and Känel, B. von. (1980): Zu den Nährstoffgehalten tischfertiger Nahrungsmittel. Alimenta, 19, 95-97.

4) Blumenthal, A., Scheffeldt, P., and Dünnenberger, G. (1981): Zu den Nährstoffgehalten tischfertiger Nahrungsmittel. Alimenta, 20, 115-119.

5) Eheart, M. S., and Gott, C. (1965): Chlorophyll, ascorbic acid and pH changes in green vegetables cooked by stir-fry, microwave and conventional methods and a comparison of chlorophyll methods. Food Technol., 867, 185-188.

6) Geervani, P., and Theophilus, F. (1980): Effect of home processing in the nutrient composition of certain high yielding legume varieties. Ind. Food Nutr. Dietic, 17, 443-446.

7) Herrmann, K., Thumann, D., Suter, G., and Nebe, G. (1973): Einfluß der Gartechniken auf den Ascorbinsäuregehalt von Kohlrabi, Rosenkohl, Blumenkohl, Bohnen und Kartoffeln. Ernähr. Umsch., 20, 438-440.

8) Hottenroth, B. (1976): Das Verhalten von Vitaminen bei der industriellen Herstellung von hizesterilisierten Dosenkonserven und bei der Zubereitung von Speisen im Haus- 
halt. Ernähr. Umsch., 23, B29-B33, 23, B33-B35, 23, B37-B38.

9) Klein, B. P., Lee, H. C., Reynolds, P. A., and Wangles, N. C. (1979): Folacin content of microwave and conventionally cooked frozen vegetables. J. Food Sci., 44, 286.

10) Klein, B. P., Kuo, C. H. Y., and Boyd, S. (1981): Folacin and ascorbic acid retention in fresh raw, microwave, and conventionally cooked Spinach. J. Food Sci., 46, 640641.

11) Martinsen, C. S., and Ostrander, J. G. (1984): Waterless cooking influence of energy consumption and nutrient retention. J. Consum. Stud. Home Econ., 8, 305-312.

12) Meier-Ploeger, A., Badelt-Vogt, A., Stettler, H., Riedel, G., and Nau, L. (1981): Einfluß verschiedener Garverfahren auf den Ascorbinsäureverlust von Kartoffeln und Kohlrabi. Ernähr. Umsch., 28, 389-392.

13) Paulus, K., and Seibel, W. (1976): Veränderungen des Vitamin- und Mineralstoffgehaltes von Nahrungsmitteln durch technologische Maßnahmen. Ernähr. Umsch., 23, 116-123.

14) Somogyi, J. C. (1975): Einfluß der Zubereitungsweise auf den Vitamin-C-Gehalt von Kartoffeln und Gemüsen. Ernähr. Umsch., 22, 42-45.

15) Somogyi, J. C., and Kopp, P. M. (1978): Einfluß der Zubereitungsweisen auf den Thiamingehalt von Kartoffeln und Gemüsen. Ernähr. Umsch., 25, 175-178.

16) Szöke, K., and Aldor, T. (1964): Über den Vitamin-C-Verlust im Gemüse während seiner Aufbewahrung. Nahrung, 8, 669-673.

17) Tempelhoff, H., Rumm-Kreuter, D., and Orlowski, G. (1978): Einfluß ausgewählter Garverfahren auf die Qualität von Tiefkühlgemüse. Ernähr. Umsch., 34, 372-376.

18) Warthesen, J. J., Vickers, Z. M., Whitney West, S., and Wolf, I. D. (1984): Cookery methods for vegetables. Influence on sensory quality, nutrient retention, and energy consumption. Home Economics Research Journal, 13, 61-79.

19) Weise, R. (1974): Beitrag zur Ermittlung des Vitamin-C-Gehaltes in Kartoffeln in Abhängigkeit der Prozeßstufen in der Großküche. Hauswirtschaft und Wissenschaft, 22, 97-105.

20) Zobel, M. (1969): Vitamin-C-Verluste bei der Speisenzubereitung unter Bedingungen einer Großküche. Hauswirtschaft und Wissenschaft, 17, 100-107.

\section{DISCUSSION-CONTRIBUTIONS}

Speaker: Rumm-Kreuter, D.

Question: Radclifle, B. (Australia)

Many chefs claim that, cooking in water with $8-10 \mathrm{~g} \mathrm{NaCl}$ per liter results in lower nutrients losses than cooking without salt. Has anyone compared nutrient losses that occur when boiling with and without added salt?

Answer: In fact there is no difference if you add salt or do not use salt. As far as I know, the additional of $\mathrm{NaCl}$ does not help. Rather important is the quantity of the water which is used for cooking. The vitamin losses are generally higher by cooking e.g. vegetables in much water.

Speaker: Rumm-Kreuter, D.

Question: Yasumoto, K.

What method are you using for the assay of vitamins particularly those known to occur 
in bound forms such as niacin and pyridoxine?

Answer: In my presentation I referred to several investigations, so different analytical methods are used. But, in all cases AOAC standard methods were applied. The determination of ascorbic acid is made by microfluorimetric, thiamin and riboflavin by fluorimetric, niacin by colorimetric and pyridoxine by microbiological measurements. To determine folic acid the microbiological method with L-casei is mostly used. Sometimes the HPLC method was applied and one notes that the losses were regularly smaller with this method. I agree that for the determination of pyridoxine, the microbiological method is not the best way (it is impossible to get all points).

Question: Yasumoto, K.

In 1977 I reported that vitamin B6 is present as glucoside. So you could not detect this form of vitamin B6 by the microbiological method. You have to hydrolyze before assaying by a microbiological method. Did you?

Answer: You are right. Pyridoxine exists in different forms. But, it was not my own investigation. I tried to make a summary of different studies. And mostly it was very difficult to compare them.

Speaker: Rumm-Kreuter, D.

Question: Mauron, J.

In potatoes you showed less in folic acid after microwave cooking. In another slide you showed increase in folic acid after microwave cooking. Do you think it is possible to increase folic acid after microwave cooking?

Answer: No, naturally it is not possible to increase the amount. If you use microwave cooking method and the amount of vegetables is small say 100 or $200 \mathrm{~g}$, the cooking duration is very short, so the losses are low. If you increase the amount of vegetables, the cooking duration will also increase and consequently the losses will be higher.

Speaker: Rumm-Kreuter, D.

Comment: Somogyi, J. C.

I wish to make a general remark. I think at this kind of investigations we should use the therm vitamin $\mathrm{C}$ instead of ascorbic acid. With most methods one determines ascorbic acid and dehydroascorbic acid. The latter is biologically active. Therefore, if we say vitamin C we mean ascorbic acid and dehydroascorbic acid. The denomination ascorbic acid excludes dehydroascorbic acid, which is still biologically active.

A further point: vitamin C losses should be calculated on dry weight basis. 